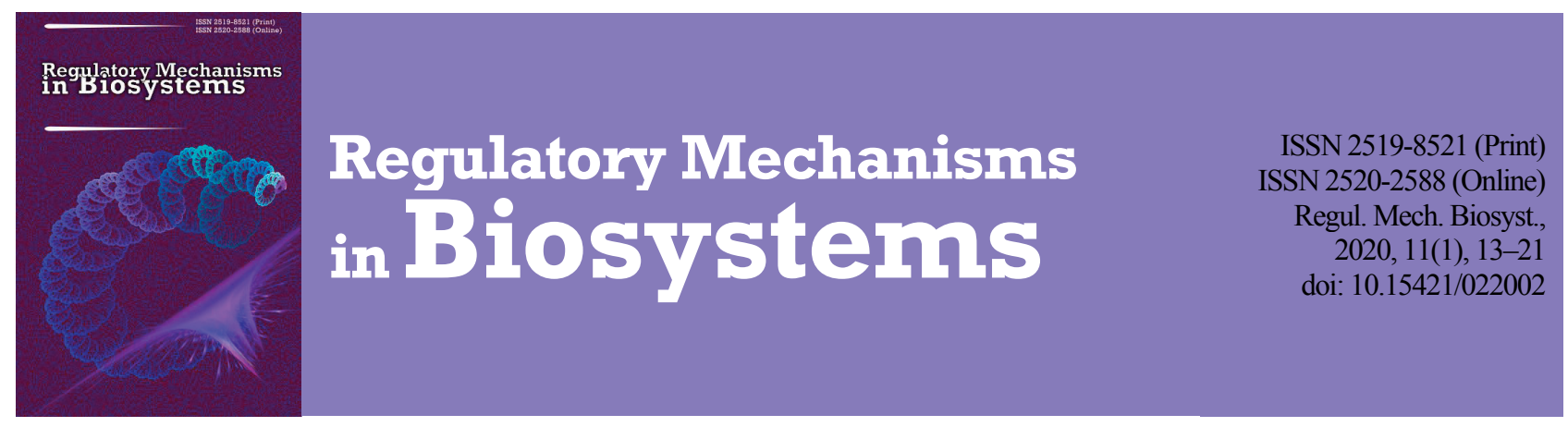

\title{
Haemodynamic effects of hyperventilation on healthy men with different levels of autonomic tone
}

\author{
V. A. Zavhorodnia*, O. I. Androshchuk*, T. H. Kharchenko**, L. I. Kudii*, S. O. Kovalenko* \\ *Cherkasy Bohdan Khmelnytsky National University, Cherkasy, Ukraine \\ **Sumy A. S. Makarenko State Pedagogical University, Sumy, Ukraine
}

Article info

Received 27.12.2019

Received in revised form 22.01.2020

Accepted 23.01.2020

Cherkasy Bohdan

Khmelnytsky

National University,

Shevchenko s.t, 81 ,

Cherkasy, 18031, Ukraine.

Tel.: +38-097-206-63-78.

E-mail:kovstas@ukr.net

Sumy A. S. Makarenko

State Pedagogical

University, Romenska st., 87

Sumy, 40002, Ukraine

Tel.: +38-050-231-24-79.

E-mail: tamara.

kharchenko88@gmail.com

Zavhorodnia, V. A., Androshchuk, O. I., Kharchenko, T. H., Kudii, L. I., \& Kovalenko, S. O. (2020). Haemodynamic effects of hyperventilation on healthy men with different levels of autonomic tone. Regulatory Mechanisms in Biosystems, 11(1), 13-21. doi:10.15421/022002

The topicality of the research is stipulated by insufficient study of the correlation between the functional state of the cardiorespiratory system and autonomic tone. The goal of the research was to analyze the changes of central haemodynamics with 10-minute regulated breathing at the rate of 30 cycles per minute and within 40 minutes of recovery after the test in healthy young men with different levels of autonomic tone. Records of the chest rheoplethysmogram were recorded on a rheograph KhAI-medica standard (KhAI-medica, Kharkiv, Ukraine), a capnogram - in a lateral flow on a infrared capnograph (Datex, Finland), and the duration of R-R intervals was determined by a Polar WIND Link in the program of Polar Protrainer 5.0 (Polar Electro OY, Finland). Systolic and diastolic blood pressure were measured by Korotkov's auscultatory method by mercury tonometer (Riester, Germany). The indicator of the normalized power of the spectrum in the range of $0.15-0.40 \mathrm{~Hz}$ was evaluated by 5 -minute records; three groups of persons were distinguished according to its distribution at rest by the method of signal deviation, namely, sympathicotonic, normotonic and parasympathicotonic. The initial level of autonomic tone was found to impact the dynamics of $\mathrm{CO}_{2}$ level in alveolar air during hyperventilation and during recovery thereafter. Thus, $\mathrm{PetCO}_{2}$ was higher $(41.3 \mathrm{~mm} \mathrm{Hg})$ in parasympathicotonic than in sympathicotonic ( $39.3 \mathrm{~mm} \mathrm{Hg}$ ) and normotonic $(39.5 \mathrm{~mm} \mathrm{Hg}$ ) persons. During the test, R-R interval duration decreased being more expressed in normotonic persons. At the same time, the heart index was found to increase in three groups, and general peripheral resistance - to decrease mostly in normo- and parasympathicotonic persons. In addition, the reliable increase of stroke index and heart index was found in these groups. In the recovery period after hyperventilation, the decrease of tension index and ejection speed was found in normo- and, particularly, parasympathicotonic compared with sympathicotonic men and the increase of tension phase and ejection phase duration.

Keywords: sympathicotonic persons; normothonic persons; vagotonic persons; central haemodynamics; hypocapnia.

\section{Introduction}

Studies of hyperventilation in the human body are quite numerous and stipulated by its presence in life activity, as well as by its application in diagnosis, correction and prediction of functional state (Eckberg et al., 2016; Burman et al., 2018; Mutch et al., 2018). Hyperventilation syndrome was described for the first time in a classic study of Da Costa (Morgan, 1983). The increase of respiratory frequency and minute volume is conditioned by the action of stress factors (military activity) on a person. With hyperventilation, there is hypocapnia, which leads to an increase in the tone of the brain vessels (Meng \& Gelb, 2015; Madureira et al., 2017; Hoiland et al., 2019). Hypocapnia is a state of the reduced carbon dioxide in the arterial blood of less than $35 \mathrm{~mm} \mathrm{Hg}$ resulting from hypodynamia (hypokinesia), stress, with deep rapid breathing (hyperventilation) caused by the increased stimulation of the central nervous system (hyperthermia, pain, fear, anxiety, hypoxemia/hypoxia, taking medication, or after intensive sport training). Its symptoms are delirium, numbness, tingling, arrhythmia, dry mouth (Bajmakanova, 2013; Ponimasov, 2016; Khiat et al., 2018). Hypocapnia can lead to mild dizziness or fainting. It has been found that after a test for hyperventilation, a decrease in the level of PetCO $\mathrm{O}_{2}$ results in the loss of consciousness and apnea with spindle activity on the EEG. However, after the test, when the carbon (IV) oxide is restored, there is a restoration of consciousness and self-breathing with the disappearance of spindle activity. Loss of consciousness is associated with the partial involvement of the ascending activating mesodiencephalic reticular formation. Hypocapnia causes microvascular spasm, oxygen deficiency, and energy starvation of the body cells. Under normal conditions, the deterioration of health resulting from hypodynamia and stress lasts for years and decades. It leads to the so-called "diseases of civilization": ischemic heart disease, hypertension, insomnia, migraine, constipation, vegetative-vascular dystonia, osteochondrosis. It has been found that the concentration of $\mathrm{CO}_{2}$ in such patients is $20-40 \%$ below normal. To achieve real recovery, it is necessary to lead the gas composition to normal, to eliminate hypocapnia (Salinet et al., 2019). Normocapnia is a condition in which the concentration of carbon dioxide in the arterial blood corresponds to $35-45 \mathrm{~mm} \mathrm{Hg}$. It has been established (Kavanagh, 2002; Drogovoz et al., 2016) that the metabolic rate of carbon monoxide (IV) at rest under standard conditions (STPD) is $150 \mathrm{~mL} / \mathrm{min}$. The body's $\mathrm{CO}_{2}$ reserves are known to be divided into several fractions. The central fraction is about $2.5 \mathrm{~L}$ and is quickly flushed with hyperventilation. The peripheral fraction is distributed in: tissues with low blood supply (fat and bone tissues), organs with moderate blood supply (muscles) and organs with intensive blood supply and low own mass (brain and kidneys) (Shurygin, 2000). The optimal concentration of carbon (IV) oxide in the arterial blood, in which the blood supply of vital organs being $100 \%$, is in the range from $6.0 \%$ to $6.5 \%$ (Mishustin, 2007; Semenov, 2016), and 5.6\% according to some sources (Lyzogub et al., 2015). A concentration of $\mathrm{CO}_{2}$ from $4.5 \%$ to $4.0 \%$ is considered to be a risk zone and from $4.0 \%$ to $3.6 \%$ - a 
zone of pathological conditions. Its further reduction from $3.6 \%$ to $3.0 \%$ indicates the possibility of life-threatening diseases. From this, it follows that the concentration of carbon dioxide in the arterial blood is the most important information and diagnostic indicator, and the development of effective ways of its normalization will contribute to maintaining good health (Shaov et al., 2009; Zav'jalova, 2011).

There are the following mechanisms to maintain normal $\mathrm{CO}_{2}$ content. They are bronchial and vascular spasm, the increased cholesterol production in the liver as a biological insulator sealing cell membranes in the lungs and vessels, lowering blood pressure (hypotension) leading to the decreased removal of carbon (IV) oxide (Zav'jalova, 2011; Drogovoz, 2017).

Molecular carbon dioxide easily crosses the blood-brain barrier and acts on the central chemoreceptors of the medulla oblongata. It is known to contain the retrotopezoid nucleus and the rostral medullary raphe, which mediate adaptive changes in breathing. The nucleus consists of a bilateral accumulation of glutamatergic neurons that respond to the enhancement of local $\mathrm{PCO}_{2}$ by cell-autonomous and paracrine (glial) mechanisms and receive additional sensory information from carotid bodies. These neurons also innervate the area of the brain stem responsible for the respiratory rhythm. The astrocytes that are the part of this nucleus affect the release of ATP depending on the change in $\mathrm{CO}_{2} / \mathrm{H}^{+}$to enhance the activity of chemosensitive neurons. The increase in carbon dioxide contributes to the release of ATP from a cell, leading to its destruction in the extracellular space and the release of adenosine, which is a powerful neuromodulator and serves to limit the functions of chemoreceptors, inhibiting hyperventilation. The rostral-medullary raphe dominated by serotonergic neurons, is believed to play a leading role in the regulation of carbon dioxide. However, $\mathrm{CO}_{2}$ affects the peripheral chemoreceptors of the aortic arch. It is estimated that $80 \%$ of carbon dioxide is perceived by central chemoreceptors, while $20 \%$ - by peripheral ones (Guyenet, 2012; Singh, 2017; Falquetto et al., 2018; Bhandare et al., 2019). The decrease in the concentration of carbon dioxide in the blood leads to an increase in oxygen affinity for haemoglobin, and therefore, in the development of hypoxia with all its consequences. The contradiction of these two haemo-stimuli presents complexity in quantifying haemodynamic reactivity, as hypoxia causes cerebral vasodilation, whereas breathing-induced hypocapnia causes vasoconstriction. However, Willie's study clearly shows the comparatively greater importance of $\mathrm{CO}_{2}$ for the regulation of cerebral blood flow (Willie et al., 2015; Lafave et al., 2019).

The dependence of the concentration of carbon dioxide and haemoglobin affinity for $\mathrm{O}_{2}$ is due to the Verigo-Bohr effect, according to which a decrease in the level of $\mathrm{CO}_{2}$ in the blood increases the binding energy of oxygen for haemoglobin and complicates its diffusion into tissues. This physiological phenomenon was discovered by B. F. Verigo, a Russian physiologist, at the end of the 19th century, and it was confirmed by C. Bohr, a Danish physician, ten years later. In the body, $\mathrm{CO}_{2}$ dissolves in the tissue fluid, forming carbonic acid, which changes the $\mathrm{pH}$ in the acidic direction: $\mathrm{CO}_{2}+\mathrm{H}_{2} \mathrm{O}=\mathrm{H}_{2} \mathrm{CO}_{3}$. The lower the $\mathrm{pH}$ of the blood, the lower the affinity of haemoglobin for oxygen. Under the influence of carbonic anhydrase, the acid dissociates into ions: $\mathrm{H}^{+}$and $\mathrm{HCO}_{3}^{-}$. The $\mathrm{HCO}_{3}^{-}$anion interacts with the $\mathrm{K}^{+}$and $\mathrm{Na}^{+}$cations, resulting in a change in the buffer equilibrium toward the alkaline reaction. It is worth noting that in plasma, $\mathrm{CO}_{2}$ dissolves slowly, and in the erythrocyte, the rate of this reaction increases thousands of times due to the presence of the enzyme. A small amount of $\mathrm{CO}_{2}$ is transferred in the compound with haemoglobin provided by nucleophilic N-centers. The physiological norm of blood $\mathrm{pH}$ ranges from 7.35-7.45, which is provided by the buffer capacity of the blood, lung and kidney function (Grishin et al., 2011; Bukov \& Belousova, 2016; Drogovoz et al., 2017). The relationship between $\mathrm{PaCO}_{2}$ and $\mathrm{pH}$ can be represented by the following rules:

- when $\mathrm{PaCO}_{2}$ increases by $20 \mathrm{~mm} \mathrm{Hg}$, the $\mathrm{pH}$ decreases by 0.1 ;

- when $\mathrm{PaCO}_{2}$ decreases by $10 \mathrm{~mm} \mathrm{Hg}$, the $\mathrm{pH}$ increases by 0.1 ;

- changes in $\mathrm{pH}$ beyond these limits are the result of metabolic disorders.

The kidneys (metabolic buffer) maintain a normal acid-base balance by dual mechanisms: reabsorption of bicarbonate $\left(\mathrm{HCO}_{3}{ }^{-}\right)$in the proxi- mal tubules or excretion in the distal nephron. These mechanisms take from several hours to several days. When the lungs and kidneys work together, the $\mathrm{pH}$ of the blood is maintained by equilibrating 1 part of acid to 20 parts of base (Bajmakanova, 2013). Impact on the reabsorption of $\mathrm{HCO}_{3}{ }^{-}$provides the effective volume of arterial blood, glomerular filtration rate, serum chloride and potassium concentration. According to the studies by Leacy et al. (2018), gradual climbing of mountains is accompanied by hypoxic hypocapnia; normal arterial $\mathrm{pH}$ is maintained by means of renal compensation. In respiratory alkalosis, the kidneys contribute to a decrease in the reabsorption of bicarbonate, i.e. $\mathrm{H}^{+}$retention and an increase in potassium bicarbonate output are observed. This process helps to maintain the $\mathrm{pH}$ of the extracellular environment to neutralize the effect of low $\mathrm{pCO}_{2}$, which is the primary disorder with respiratory alkalosis (Leacy et al., 2018). In the studies of Zouboules et al. (2018), the concept of renal reactivity index is introduced showing the dependence of bicarbonate and $\mathrm{PaCO}_{2}$ concentration during gradual climbing to a height. Strong negative correlation is found between these indicators $(\mathrm{r}<0.71 ; \mathrm{P}<0.001)$ from the baseline at all heights (Zouboules et al., 2018).

The revealed changes of EEG during the prolonged hyperventilation are found to depend directly on the level of carbon (IV) oxide. Hypocapnia with a $\mathrm{CO}_{2}$ concentration of $15 \mathrm{~mm} \mathrm{Hg}$ causes a more active intensification of both intracortical and deep limbic-reticular effects of the brain, which are manifested in the increase of all types of cerebral activity, and in more than $70 \%$ in the generalized paroxysmal activity. The recovery of the original EEG pattern after hyperventilation occurs long before the restoration of the carbon dioxide voltage (Djomin \& Poskotinova, 2017).

Carbon dioxide in physiological concentrations affects the tone of smooth muscles, expands the small arteries and capillaries in the place of spasm, normalizes the tone of veins, relieves spasm, and tones the atonic smooth muscles of all organs. It also reduces the viscosity of colloidal solutions improving metabolism and the increased speed of biochemical processes (Lyzogub et al., 2015).

The increase in the tone of the cerebral arteries under the action of hypocapnia is considered to be a compensatory mechanism in response to a decrease in the heart rate and pulse blood flow. Carbonic acid in humoral and reflexive way from the chemoreceptors of the vascular zones has a stimulating effect on the reticular formation of the trunk and then on the cerebral cortex. Reducing the partial pressure of $\mathrm{CO}_{2}$ in the blood is accompanied by a decrease in stimulating effects and leads to the increased thalamic-cortical synchronization, activation of the anterior parts of the hypothalamus and hypertension of the cortex. Under the influence of hypocapnia and gas alkalosis, there is a spasm of the brain vessels, which leads to a decrease in the supply of oxygen and glucose to the brain with transient hypoxia and ischemia accompanied by a decrease in frequency and an increase in alpha rhythm and delta activity. Changes in the form of an increase in alpha rhythm synchronization, the appearance of bilateral synchrony, the intensification of slow-wave outbreaks in the anterior parts may be explained by the indirect influence on the hypothalamic-diencephalic structures (Gnezdickij et al., 2010).

Gas alkalosis in hyperventilation has a specific effect on vascular tone and causes narrowing not only of the brain vessels but also coronary and peripheral ones, the vessels of intestines, liver, kidneys; at the same time, there is an expansion of skeletal muscle vessels. There is a redistribution of regional circulation and reduction of coronary and cerebral blood flow. It is proved that the majority of patients with acute stroke are hypocapnic (Curley et al., 2010; Grishin et al., 2012; Nagibovich et al., 2016; Salinet et al., 2019).

Hypocapnia is found to cause a decrease in the heart rate variability and an increase in the variability of QT interval on the electrocardiogram, an increase in the heart rate. At the same time, slow breathing with a low inhalation-exhalation rate, accompanied by hypercapnia, is associated with greater power in the high-frequency component of heart rate variability (Sullivan et al., 2004; Van Diest et al., 2014).

Numerous studies show that changes in the diameter of the internal carotid artery is positively associated with the reactivity of $\mathrm{PaCO}_{2}$ $(\sim 25 \%)$, while the spinal artery cross-section does not respond to the change in $\mathrm{CO}_{2}$ in the arterial blood, but with severe hypoxia, $9 \%$ in- 
crease in its diameter is observed (Willie et al., 2012; Sato et al., 2012). At the same time, the blood flow rate is characterized with less reactivity in the anterior and posterior cerebral arteries than in the vertebral and carotid.

Arbitrary hyperventilation is accompanied by changes in autonomic nerve regulation with a predominance of sympathetic effects leading to anger and panic attacks. Changes in cardiac activity and haemodynamics, decrease in the functionality of distant analyzers, and the level of psychomotor performance deepened with the increase in hypocapnia, are observed. The decrease in the activity of the respiratory center during hyperventilation, leads to a change in the propagation of excitation from it to the cortex of the cerebral hemispheres and spinal motor centers. Hypocapnia-induced vasoconstriction significantly inhibits neural activity (Szabo et al., 2011; Nagibovich et al., 2016). It was confirmed that the reduction of carbon dioxide in the body stimulated the coagulation function of the blood, contributing to the development of thrombophlebitis in combination with the slow blood flow in the veins. Hypocapnia leads to increased mucus secretion in the bronchi, nasal passages, development of adenoids and polyps. There is a thickening of membranes due to the accumulation of cholesterol contributing to the development of tissue sclerosis. Endogenous catecholamine release is activated (Grishin et al., 2012; Lyzogub et al., 2015).

It is established that the decrease in $\mathrm{PCO}_{2}$ in the lungs causes vasodilation; in the gastrointestinal system, there are changes in perfusion, treatment of electrolytes and motility: the tone of the colon increases and the phase contractility in the transverse and sigmoid region increases, which can be explained by the suppression of sympathetic innervation and the direct effect of hypocapnia on the smooth muscles of the intestine (Foster et al., 2001; Panina, 2003; Grishin et al., 2012; Sur \& Shah, 2019).

The physiological concentration of carbon dioxide has a positive effect on the permeability of membranes, namely, it normalizes the excitability of nerve cells. It helps to withstand stress, to avoid nervous overstimulation and, as a consequence, to relieve insomnia and migraines. It also stimulates the release of vasoactive substances as histamine, acetylcholine, serotonin, and kinins by nerve endings; these substances expand coronary vessels and result in a decrease of the heart rate and blood pressure (Makarenkova et al., 2012). At the same time, the excitability of nerve fibers increases as with the hyperventilation. As $\mathrm{Ca}^{2+}$ and $\mathrm{H}^{+}$ions competitively bind to plasma proteins, a decrease in the $\mathrm{H}^{+}$ concentration causes an increase in the number of the bound $\mathrm{Ca}^{2+}$ ions. Their content in plasma and intercellular fluid decreases, leading to a decrease in transmembrane potential and an increase in the permeability of the cell membrane for $\mathrm{Na}^{+}$ions. Besides, the reduction of $\mathrm{Ca}^{2+}$ in the extracellular fluid influences myocardial contraction force (Panina, 2003; Makarenkova et al., 2012).

Pregnant women are found to be also exposed to hypocapnia (30.7 \pm $3.7 \mathrm{~mm} \mathrm{Hg}$ ), and especially women in the second stage of childbirth, in which even lower values of $\mathrm{PetCO}_{2}(20.8 \pm 5.9 \mathrm{~mm} \mathrm{Hg})$ are detected, which probably affects the optimal cerebral oxygenation of the fetus (Tomimatsu et al., 2012).

The $\mathrm{CO}_{2}$ introduced into the body creates a state of hypercapnia accompanied with vasodilation being the result of its direct activity on the smooth muscle cells of arterioles, an increase in capillary blood flow and, as a consequence, an increase in tissue oxygenation. Carbon (IV) oxide stimulates the secretion of growth factors, such as vascular endothelial growth factor, which results in the formation of new blood vessels (neovascularization) and revascularization. The state of hypercapnia is not harmful to the body, since excess gas can simply be removed through the lungs. The introduction of carbon dioxide is often used to treat lymphatic stagnation, since its vasodilator effect enhances tissue perfusion and improves local blood flow, leading to a decrease in lymphedema (Khiat et al., 2018).

An increase in $\mathrm{CO}_{2}$ concentration leads to an increase in the rate of cerebral blood flow, and its decrease - to a decrease; besides, with hyperventilation, intracranial pressure is reduced due to the induction of cerebral vasoconstriction with a further decrease in cerebral blood volume. The cross-sectional area of the middle cerebral artery is found to increase by approximately $8 \%$ during hypercapnia. The reaction of the rate of cerebral blood flow to the concentration of carbon dioxide is due to changes in the resistance of cerebral resistance vessels, the mechanism of which has not been fully studied. Vasodilation with the introduction of carbon (IV) oxide is possibly due to the accumulation of $\mathrm{H}^{+}$and activation of $\mathrm{K}^{+}$channels in vascular smooth muscle cells. Carbon dioxide also increases average blood pressure (BP, with reverse breathing for more than $2 \mathrm{~min}$ ), which can lead to an increase in perfusion pressure against autoregulation failure and affect the speed of cerebral blood flow. Thus, a threshold of $\mathrm{PetCO}_{2}(42 \mathrm{~mm} \mathrm{Hg})$ is found; to achieve it, the enhancement of cerebral blood flow reflects true cerebrovascular reactivity to carbon dioxide without the dependence on changes in systemic BP. It may be stipulated by not only the vasodilating effect of carbon (IV) oxide, but also by increasing the perfusion pressure with the growth of systemic BP (Stocchetti et al., 2005; Kulikov et al., 2017).

It has been investigated that raising $\mathrm{CO}_{2}$ to $0.7-1.2 \%$ within 23 days contributes to a $35 \%$ increase in the rate of cerebral blood flow compared to the background during the first 1-3 days, after which this indicator gradually decreases to the previous level. Time-dependent changes in vascular reactivity may be stipulated by either a delay in bicarbonate in the extracellular brain fluid, or a progressive increase in ventilation, or both ones (Cassaglia et al., 2008; Miller et al., 2018).

Hypercapnia has been shown to increase the diameter of the inferior vena cava, leading to a decrease in venous return of the blood, resulting in a decrease in cardiac output. An increase in $\mathrm{CO}_{2}$ concentration contributes to a decrease in peripheral vascular resistance, right ventricular hypertrophy, and arrhythmias. It also produces negative inotropic and chronotropic effects (the occurrence of bradycardia), due to changes in the sensitivity of the vagus nerve nuclei to the influence of $\mathrm{CO}_{2}$, which slows the cardiac output. The action of carbon dioxide expands the peripheral arterioles, resulting in redistribution of blood in favour of an increase in peripheral volume, with the filtration equilibrium point in the capillaries shifting distally, causing fluid movement beyond the vascular bed and the loss of plasma volume. Accordingly, the effective volume of circulation decreases, which stimulates the sympathetic nervous system, the production of renin and vasopressin. In order to maintain intravascular volume, the kidneys respond by vasoconstriction and retain sodium (Shoemaker et al., 2001; Baković et al., 2006; Gavrisjuk, 2006). Hypercarbia has been shown to decrease blood flow in the hepatic, renal, and musculoskeletal flow, while gastrointestinal, myocardial, and cerebral blood flow increase. There is also a decrease in blood pressure (Solov'eva et al., 2013; Coverdale et al., 2016).

In their study Harrison et al. (2017), the observation of video-based surgery shows an increase in respiratory rate and a decrease in etCO $\mathrm{CO}_{2}$ in women. At the same time, there are significant shifts in haemodynamics. A meta-analysis of the literature shows that stroke survivors have low levels of $\mathrm{CO}_{2}$ in the blood and cerebral blood flow (Salinet et al., 2019). Several studies show that hypocapnia with hyperventilation affects not only the level of blood flow in the brain but also modulates its response to various stimuli (Boulet et al., 2016; Smielewski et al., 2018; Tsuji et al., 2018).

Hyperventilation and the shortness of breath coming after it significantly increase coronary blood flow. Thus, in experiments on anesthetized pigs, shortness of breath after hyperventilation led to a significant increase in coronary blood flow, which was determined with magnetic resonance (by 346\% compared with 97\% increase during shortness of breath). In coronary artery stenosis, the differences were leveled (Fischer et al., 2016). However, hyperventilation followed by shortness of breath was successfully used as a non-pharmacological vasoactive impulse to stimulate changes in the oxygenation of myocardium including in patients with coronary heart disease (Fischer et al., 2018). Allan's work (Allan et al., 2015) shows that hyperventilation leads to an increase in blood pressure variability in patients with ischemic attack.

The reactivity of the cardiovascular system to physiological stimuli in healthy people may vary significantly depending on the conditions (Lutsenko \& Kovalenko, 2017) and be determined by individual and typological characteristics (Kovalenko \& Kudii, 2006). One of these typological indicators is the level of autonomic tone (Spitsin et al., 2018). It is proved that its initial level can determine the nature of the body's response to stress (Wilder, 1957). 
Therefore, the purpose of our research is to study changes in central haemodynamics with 10-minute regulated breathing at a rate of 30 cycles per minute and during recovery after the test in healthy men with different levels of autonomic tone.

\section{Materials and methods}

The study was conducted in compliance with the basic bioethical principles of the European Council Convention on Human Rights and Biomedicine (04.04.1997), Helsinki Declaration of the World Medical Association on Ethical Principles of Conducting Medical Research Involving Human Subjects (1994-2008), the Order of Ministry of Healthcare (Ukraine) No 690 dated 23.09.2009. All participants gave written permission for participation in the measurements and for publication of their results. The measurements were made on 77 healthy young men aged 18-23 years (an average age $20.23 \pm 0.18$ ) under conditions close to the state of basal metabolism. All persons participated in the study voluntarily, were found to be healthy according to the medical examina- tion, did not have acute and chronic diseases. Before completing the tasks, they were informed of the purpose and objectives of the measurements, the sequence and the content of the test loads, and gave written permission for the research and the scientific use of their results. The day before the examination, the subjects did not drink alcohol, coffee, stimulants or sedatives, did not have great emotional and physical activity. Breath capnography, chest rheoplethysmogram, cardio intervals were recorded for 5 minutes while sitting quietly, for 10 minutes of the regulated breathing at a frequency of 30 cycles per minute and 40 minutes of the recovery period after the test.

The chest rheoplethysmogram was registered on the rheograph of XAI-medica standard (XAI-medica, Kharkiv, Ukraina) (Fig. 1), capnogram - in the lateral flow on the capnograph of DATEX NORMOCAP (Datex, Finland); the duration of R-R intervals was determined with the cardio sensor of Polar WIND Link, the receiver of Polar Windlink in the program of Polar Protrainer 5.0 (Polar Electro OY, Finland). Systolic (APs) and diastolic (APs) arterial blood pressure was measured with Korotkov's auscultative method by mercury tonometer (Riester, Germany).

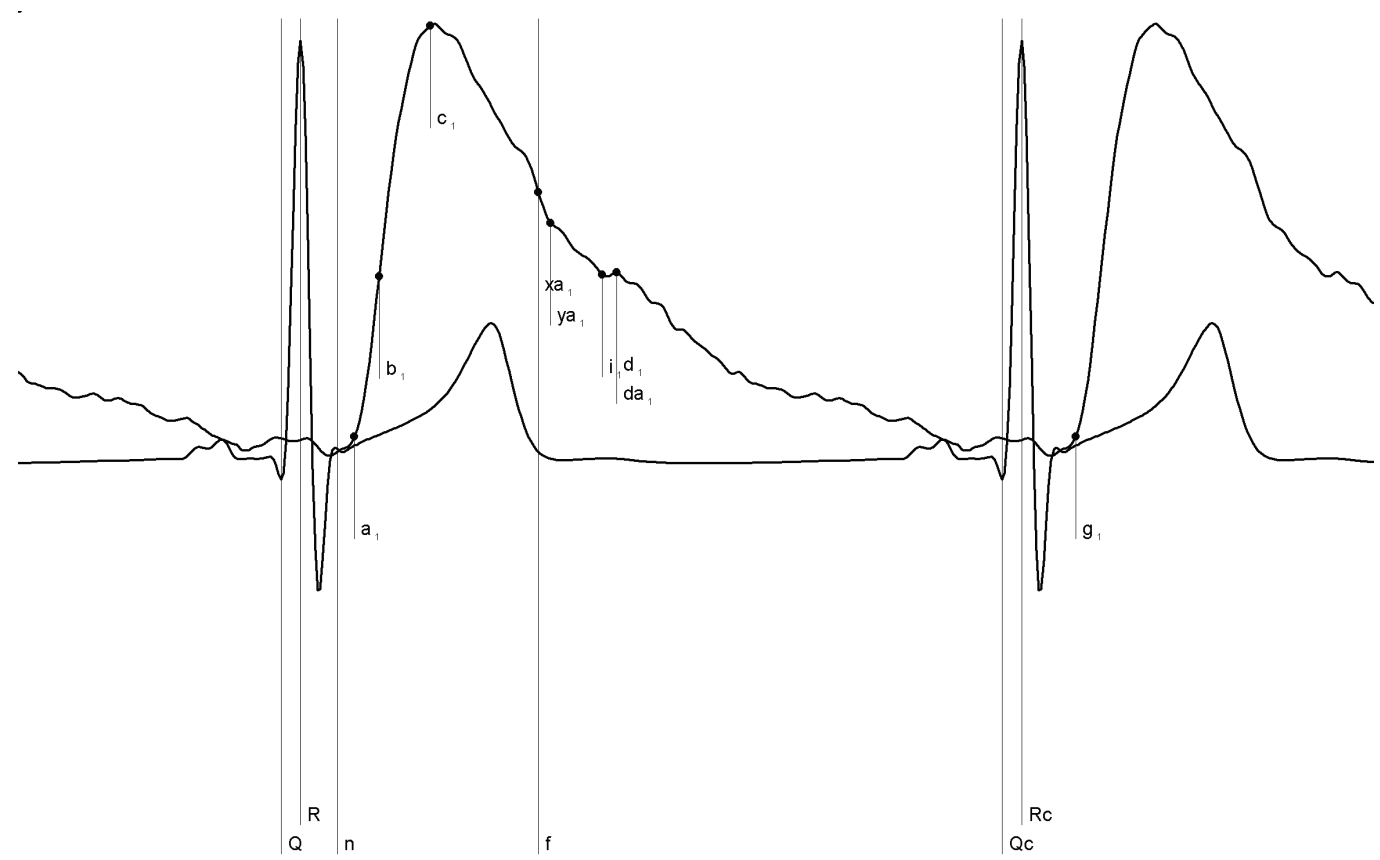

Fig. 1. Fragment of ECG and chest rheogram record with critical points for calculating central haemodynamics and cardiodynamics: on the abscissa axis - amplitudes of signals; on the ordinate axis - time of recording

$\mathrm{CO}_{2}$ level at the end of exhalation $\left(\mathrm{PetCO}_{2}\right)$ was evaluated according to capnogram. The average blood pressure (APm) was calculated by the formula of Hickkam (Ramaat et al., 2003). Stroke volume indicator (SV) was given by the formula of W. G. Kubicek (Kubichek, 1970). The duration of tension phase (TPh), ejection phase $(\mathrm{EPh})$, stroke index (SI), heart index (HI), general peripheral resistance (GPR), ejection speed (ES) were calculated according to generally accepted methods (Klabunde, 2012). Tension index (TI) was calculated as a ratio of TPh to EPh in percentage.

An indicator of the normalized power of the spectrum in the range of $0.15-0.4 \mathrm{~Hz}$ (HFnorm) reflecting the level of vagosympathetic balance was evaluated according to 5-minute records of cardiointervalogram at rest and under experimental influences (Malik et al., 2019). Three groups of persons were distinguished according to this indicator at rest by the method of signal deviations; they are sympathicotonic (I, $n=22$ ) up to 40 conditional units (c.u.), normotonic (II, $n=30$ ) from 40 to 60 c.u., and parasympathicotonic ones (III, $n=25$ ) from 60 c.u.

The physiological indicators was evaluated as the difference between their level during the experimental influences and in the background. Statistical analysis due to the normality of sample distribution (by Shapiro-Wilk test) was made by parametric methods. The data in the tables and text are presented as mean \pm standard error $(\mathrm{x} \pm \mathrm{SE})$. The probability of differences was estimated Fisher's F-test by ANOVA method.

\section{Results}

There were differences in PetCO2 and central haemodynamics functioning at rest depending on the initial level of autonomic tone. Thus, in the parasympathicotonic persons, PetCO2 was higher $(41.29 \pm$ $0.50 \mathrm{~mm} \mathrm{Hg}, \mathrm{P}<0.01)$ than in group I $(39.28 \pm 0.77 \mathrm{~mm} \mathrm{Hg}, \mathrm{P}<0.01)$ and II $(39.45 \pm 0.61 \mathrm{~mm} \mathrm{Hg}, \mathrm{P}<0.01)$. Immediately after the start of the regulated breathing at a rate of 30 cycles per minute, there was a significant decrease in $\mathrm{PetCO}_{2}$ in all groups with its lowest values reached in the 5-7 minutes of the test (Fig. 1). During the test, the decrease in $\mathrm{PetCO}_{2}$ was observed to be more expressed in normotonic persons $(-23.07 \pm 0.85 \mathrm{~mm} \mathrm{Hg})$ compared to group I $(-20.19 \pm 1.35 \mathrm{~mm} \mathrm{Hg}$, $\mathrm{P}<0.05)$ and III $(-20.10 \pm 1.02 \mathrm{~mm} \mathrm{Hg}, \mathrm{P}<0.01)$. After the test with hyperventilation, $\mathrm{PetCO}_{2}$ was rapidly increased. This indicator was not restored to the initial values in any typological group up to 40 minutes of registration after the test.

Higher diastolic blood pressure (APd) was registered in sympathicotonic persons compared to group III $(79.3 \pm 1.7 \mathrm{~mm} \mathrm{Hg}$ and $75.2 \pm$ $1.3 \mathrm{~mm} \mathrm{Hg}, \mathrm{P}<0.05$ respectively) and APm $(94.1 \pm 1.9 \mathrm{~mm} \mathrm{Hg}$ and $90.9 \pm 1.3 \mathrm{~mm} \mathrm{Hg}, \mathrm{P}<0.05$ respectively). This trend was observed throughout the study. However, the normotonic persons were characterized with the highest reactivity at the end of recovery period APm $(0.33 \pm 0.43 \mathrm{~mm} \mathrm{Hg}, \mathrm{P}<0.05)$. 


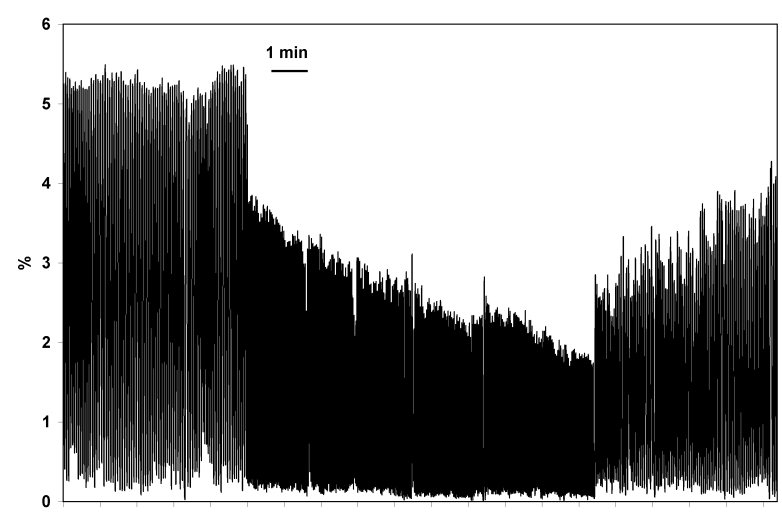

Fig. 2. Fragment of the original record of breath capnogram at rest, during the test with hyperventilation (breathing rate being 30 cycles per minute) and the part of recovery period: on the abscissa axis - concentration of carbon

(IV) oxide in expiration air; on the ordinate axis - time of recording
In the background, the men of group I were characterized by shorter duration of R-R intervals and lower SI values compared to group II and III (Table 1). At the same time, the duration of R-R intervals was shorter in normotonic subjects than in vagotonic ones.

During the test on hyperventilation, a decrease in $\mathrm{t}-\mathrm{R}-\mathrm{R}$ was registered being the most expressed in group II; its reactivity at the end of the test was $134 \pm 19.7 \mathrm{~ms}(\mathrm{P}<0.05)$; a decrease in SI was observed in the edge groups with the highest reactivity in vagotonic subjects $(-1.94 \pm$ $\left.1.74 \mathrm{~mL} / \mathrm{m}^{2}, \mathrm{P}<0.05\right)$; a decrease in GPR was found to a greater extent in groups II and III. An increase in HI was found in all groups during the test with the least reactivity in parasympathicotonic subjects being $0.18 \pm 0.09 \mathrm{~L} / \mathrm{m}^{2} \cdot \mathrm{min}(\mathrm{P}<0.05)$ on 5 -minute test.

In the recovery period, an increase in t-R-R and SI was found in all typological groups. After the test, the least SI reactivity was found in sympathicotonic subjects $\left(-1.88 \pm 1.34 \mathrm{~mL} / \mathrm{m}^{2}, \mathrm{P}<0.05\right)$, while the least GPR reactivity was observed in the normotonic group $(-29.0 \pm$ $\left.91.7 \mathrm{dyn} / \mathrm{s}^{\bullet} \mathrm{cm}^{5}, \mathrm{P}<0.05\right)$.

Certain differences were found in the indicators of cardiodynamics between the persons with different initial level of autonomic tone (Table 2).

Table 1

Central haemodynamics indicators during and after the test of the regulated breathing at a rate of 30 cycles per minute in healthy young men with different initial levels of autonomic tone $(x \pm S E)$

\begin{tabular}{|c|c|c|c|c|c|c|}
\hline Indicators & Groups & Background & Test (5 min) & Test $(10 \mathrm{~min})$ & Recovery (5 min) & Recovery (40 min) \\
\hline \multirow{3}{*}{$\mathrm{t}-\mathrm{R}-\mathrm{R}, \mathrm{ms}$} & I & $798.4 \pm 23.2$ & $691.1 \pm 20.1$ & $722.8 \pm 21.1$ & $865.6 \pm 23.8$ & $857.5 \pm 22.1$ \\
\hline & II & $884.4 \pm 23.2^{*}$ & $750.1 \pm 23.5^{*}$ & $780.1 \pm 23.8^{*}$ & $914.0 \pm 26.6^{*}$ & $912.1 \pm 31.0 *$ \\
\hline & III & $959.3 \pm 30.3^{* \#}$ & $744.0 \pm 26.5^{*}$ & $795.8 \pm 31.0 *$ & $993.0 \pm 26.9 *$ & $998.5 \pm 29.5^{* \#}$ \\
\hline \multirow{3}{*}{$\mathrm{SI}, \mathrm{mL} / \mathrm{m}^{2}$} & $\mathrm{I}$ & $29.14 \pm 1.73$ & $29.50 \pm 1.82$ & $28.80 \pm 1.66$ & $29.12 \pm 1.72$ & $29.71 \pm 1.59$ \\
\hline & II & $35.63 \pm 2.25^{*}$ & $35.65 \pm 2.07^{*}$ & $36.73 \pm 1.99 *$ & $38.19 \pm 3.24 *$ & $36.83 \pm 2.43^{*}$ \\
\hline & III & $40.02 \pm 3.04^{*}$ & $35.54 \pm 1.95^{*}$ & $37.89 \pm 2.12 *$ & $40.72 \pm 2.74 *$ & $41.96 \pm 3.07 *$ \\
\hline \multirow{3}{*}{$\mathrm{HI}, \mathrm{L} / \mathrm{m}^{2} \cdot \min$} & I & $2.19 \pm 0.11$ & $2.41 \pm 0.12$ & $2.38 \pm 0.11$ & $1.98 \pm 0.08$ & $2.01 \pm 0.08$ \\
\hline & II & $2.36 \pm 0.12$ & $2.76 \pm 0.14^{*}$ & $2.75 \pm 0.12 *$ & $2.38 \pm 0.15^{*}$ & $2.26 \pm 0.11^{*}$ \\
\hline & III & $2.43 \pm 0.16$ & $2.86 \pm 0.17^{*}$ & $2.84 \pm 0.15^{*}$ & $2.40 \pm 0.15^{*}$ & $2.45 \pm 0.16^{*}$ \\
\hline \multirow{3}{*}{ GPR, dyn $/ \mathrm{s}^{\cdot} \mathrm{cm}^{5}$} & I & $1848.0 \pm 88.3$ & $1681.0 \pm 78.8$ & $1708.6 \pm 78.1$ & $2038.9 \pm 98.9$ & $1970.6 \pm 85.6$ \\
\hline & II & $1838.4 \pm 144.9$ & $1521.4 \pm 77.2 *$ & $1509.9 \pm 83.5^{*}$ & $1844.3 \pm 122.8$ & $1845.7 \pm 136.9$ \\
\hline & III & $1790.8 \pm 134.7$ & $1473.0 \pm 92.9 *$ & $1457.5 \pm 74.8^{*}$ & $1765.0 \pm 98.7^{*}$ & $1818.0 \pm 147.7$ \\
\hline
\end{tabular}

Note: ${ }^{*}-\mathrm{P}<0.05$ compared to group I; ${ }^{\#}-\mathrm{P}<0.05$ when comparing group II and III; by ANOVA method with Bonferroni correction.

Table 2

Cardiodynamics indicators during and after the test of regulated breathing at a rate of 30 cycles per minute in healthy young men with different initial levels of autonomic tone $(x \pm S E)$

\begin{tabular}{|c|c|c|c|c|c|c|}
\hline Indicators & Groups & Background & Test (5 min) & Test (10 min) & Recovery (5 min) & Recovery (40 min) \\
\hline & $\mathrm{I}$ & $138.7 \pm 4.5$ & $137.6 \pm 4.2$ & $139.4 \pm 4.2$ & $136.1 \pm 5.3$ & $144.5 \pm 4.8$ \\
\hline \multirow[t]{3}{*}{$\mathrm{TPh}, \mathrm{ms}$} & II & $129.7 \pm 2.9^{*}$ & $129.2 \pm 2.8^{*}$ & $130.0 \pm 2.7^{*}$ & $136.0 \pm 3.4^{*}$ & $134.6 \pm 3.4^{*}$ \\
\hline & III & $128.0 \pm 3.3^{*}$ & $127.2 \pm 3.3^{*}$ & $130.0 \pm 3.6^{*}$ & $135.0 \pm 3.6^{*}$ & $134.4 \pm 3.4^{*}$ \\
\hline & I & $233.6 \pm 4.3$ & $234.5 \pm 4.3$ & $237.4 \pm 4.0$ & $248.1 \pm 4.7$ & $246.5 \pm 4.1$ \\
\hline \multirow[t]{3}{*}{$\mathrm{EPh}, \mathrm{ms}$} & II & $239.8 \pm 7.0$ & $241.8 \pm 6.0$ & $249.4 \pm 4.8^{*}$ & $269.7 \pm 13.2 *$ & $259.7 \pm 12.0$ \\
\hline & III & $264.9 \pm 15.6^{* \#}$ & $240.3 \pm 5.3$ & $262.5 \pm 9.7^{*}$ & $288.9 \pm 16.0^{*}$ & $294.4 \pm 19.3^{* \#}$ \\
\hline & $\mathrm{I}$ & $37.1 \pm 1.0$ & $36.9 \pm 0.8$ & $36.9 \pm 0.8$ & $36.9 \pm 1.0$ & $36.8 \pm 0.9$ \\
\hline \multirow[t]{3}{*}{ TI, \% } & II & $35.3 \pm 0.8$ & $34.9 \pm 0.6^{*}$ & $34.3 \pm 0.6^{*}$ & $34.1 \pm 1.0^{*}$ & $34.7 \pm 0.9 *$ \\
\hline & III & $33.4 \pm 1.0^{* \#}$ & $34.6 \pm 0.7^{*}$ & $33.3 \pm 0.7^{*}$ & $32.5 \pm 1.0^{*}$ & $32.4 \pm 1.2^{* \#}$ \\
\hline & $\mathrm{I}$ & $219.0 \pm 9.9$ & $219.5 \pm 9.4$ & $212.5 \pm 9.3$ & $205.6 \pm 8.8$ & $212.2 \pm 8.9$ \\
\hline \multirow[t]{2}{*}{$\mathrm{ES}, \mathrm{mL} / \mathrm{s}$} & II & $254.9 \pm 11.7^{*}$ & $254.2 \pm 11.6^{*}$ & $254.1 \pm 11.4^{*}$ & $240.9 \pm 11.2 *$ & $245.4 \pm 10.7^{*}$ \\
\hline & III & $257.2 \pm 11.7^{*}$ & $253.7 \pm 13.8^{*}$ & $248.5 \pm 13.2^{*}$ & $243.1 \pm 12.7 *$ & $245.4 \pm 12.0^{*}$ \\
\hline
\end{tabular}

Note: ${ }^{*}-\mathrm{P}<0.05$ compared to group I; ${ }^{\#}-\mathrm{P}<0.05$ when comparing group II and III; by ANOVA method with Bonferroni correction.

Thus, in the background, high TI and, accordingly, TPh, as well as the shortest EPh and ES were observed in sympathicotonic subjects. A decrease in $\mathrm{TPh}$, TI was found during hyperventilation especially in the men of group III compared to group I. The highest TI reactivity was determined in sympathicotonic subjects $(-1.09 \pm 0.94 \%, \mathrm{P}<0.05)$. In the recovery period, a decrease in TI was found in group II and especially in group III compared to group I. After the functional test, a trend to an increase haemodynamic indicators among the subjects was observed, that is a normal reaction of cardiovascular system in response to load and which is conditioned by the influence of the sympathetic-adrenal link of the autonomic nervous system.

\section{Discussion}

The regularities identified in our studies are largely confirmed and explained by the analysis of other researches on the reactivity of different systems of human body depending on the initial level of autonomic tone. Thus, the study of Skyba et al (2017) evaluated the functional state of the autonomic nervous system according to the indicators of heart rate variability with the determination of the initial autonomic tone and autonomic reactivity in athletes with different levels of sensorimotor reactivity. The autonomic tone, identified among most athletes with a medium level of sensorimotor response, was characterized by a background eutonia, and sympathicotonia was significantly more prevalent among the group of athletes with a high level of sensorimotor response compared to the athletes with its medium and low level. Autonomic imbalance, manifested by hypersympathicotonic reactivity, was determined among the athletes with high and medium levels of sensorimotor response, which indicated the tension of the cardiovascular system functioning and reduction in the adaptive capacity of the body. The importance of considering the autonomic tone in the pathologies of the cardiovascular system in sleep disorders is 
discussed (Tamisier et al., 2018). The enhanced autonomic tone along with various stimuli, such as intermittent hypoxia, broken continuity of sleep, reduction of its duration, the increased respiratory effort and shortterm hypercapnia can initiate a cascade of pathological changes leading to the deterioration of a person's condition.

The haemodynamics measurements of pregnant women by Doppler fluometry shows that the performance of the fetus heart is significantly influenced by the mother's autonomic tone level (Lakhno, 2017). Fetal circulation disorders are formed in response to the increased sympathetic and decreased vagal tone.

The confirmation of typological features of cardiovascular system response to any stimuli is genetic research. Sigurdsson et al. (2018) demonstrate that there is a genetic determination for most parameters of autonomic equilibrium. Genetic conditioning for blood pressure and cardiac activity has been clarified. However, the reactivity of haemodynamics on loading, changes in autonomic tone depends on the activity of many genes and can be analyzed by polygenic methods.

According to a meta-analysis of the literature, the origin of heart rate waves in the high frequency range $0.15-0.40 \mathrm{~Hz}(\mathrm{HF})$ is almost uniformly interpreted. These waves are the reflection of respiratory sinus arrhythmia (Novak et al., 1994; Linden \& Diehl, 1996). An important component of high-frequency component of R-R interval oscillations is shown to be efferent vagal activity with electrical stimulation of the vagus, vagotomy, blockade of muscarinic receptors (Akselrod et al., 1981; Pomeranz et al., 1985; Malliani et al., 1991). At the same time, there is an opinion about the complex nature of high-frequency oscillations (Malliani, 1996). In measurements (Appel et al., 1989) hypothesized that the high-frequency component was represented in the parasympathetic and sympathetic efferent impulse, but the low transmission of sympathetic effects almost completely eliminates the high-frequency sympathetic rhythm (Introna et al., 1995). Thus, in patients with spinal anesthesia, the spread of the spinal block reached high thoracic segments (higher than $\mathrm{T}_{3}$ ) and a decrease in variability was observed not only in the low but also high frequencies.

At the same time, in experiments on cats (Shejh-Zade et al., 2001), after complete denervation of the heart, the respiratory peak is always determined on the heart rate spectrogram, which indicates the ability of the sinoatrial node to change its automatism under the influence of the respiratory fluctuations of venous return. The oscillation of systolic blood pressure or blood stroke volume in this range is found to depend on the depth of breath movements (Sanderson et al., 1996; Bouteau \& Tavernier, 2004). The amplitude of these waves depends on the level of fluid in the body (Wiesenack et al., 2005).

The genesis of low-frequency waves of heart rhythm remains controversial as some authors believe that their normalized power reflects the activity of the sympathetic division of autonomic nervous system (Kamath \& Fallen, 1993; Guzzetti et al., 1994; Malliani et al., 1994; Montano et al., 1994; Lucini et al., 1997; Sesay et al., 2008), others tend to think of both sympathetic and parasympathetic influences in the formation of these oscillations (Appel et al., 1989).

There are several hypotheses for the mechanisms of low-frequency waves of blood pressure and heart rate (Malliani, 1998; Hajutin \& Lukoshkova, 1999). The basic assumption is that such oscillations are the result of periodic amplification and attenuation of signal flow of arterial baroreceptors at the stroke of blood pressure waves of the third order (Hajutin \& Lukoshkova, 1999). Thus, when blood pressure lowers, baroreceptor signals accelerate the heart rate; and they slow it down with high blood pressure. The period duration of such oscillations (8-12 s) is determined by the delay sum in the process time in the efferent branch of reflex baroreceptor arc (Bernardi et al., 1997). However, the LF component increases under the conditions of emotional stress or physical exertion when pressure increases; and barro-reflex impulse increases (Malliani et al., 1991). The power of slow waves increases under the conditions of experimental regional myocardial ischemia in dogs without any changes in blood pressure (Rimoldi et al., 1990). Such changes may be the consequences of an increase in norepinephrine content in blood. This is confirmed by experiments performed during surgery in patients with pheochromocytoma. The level of norepinephrine concentration in blood plasma correlates with the power of the low-frequency component of the R-R interval spectrum $(r=0.68)$ (Sesay et al., 2008).
It has been noted (Jansen et al., 1995) that long waves can also occur due to the rhythmic nature of the myogenic reactions of arterioles. It has been established (Myers et al., 2001) that sympathetic influences modulate the Mayer waves due to changes in the resistance of peripheral vessels.

According to some studies (Cevese et al., 1995), slow heart rate waves are of centrogenic origin. It is believed that there is a rhythmic activity with a period of about $10 \mathrm{~s}$ of parasympathetic and sympathetic cardiomotor neurons of the brain stem. Some measurements (Inoua et al., 1990) show the absence of LF component in the patients with quadriplegia. This was explained by the destruction of the neural pathways that transmit rhythms from the brain to the spinal cord. At the same time, it was shown (Guzzetti et al., 1994; Koh et al., 1994) that there were slow waves of R-R interval and blood pressure in some patients with such disorders. These phenomena were interpreted as manifestations of spinal rhythmics affecting vascular background and sinus pacemaker activity (Guzzetti et al., 1994). It was found (Cooley et al., 1998) that there were no waves in the spectra of blood pressure, R-R interval, and respiratory rate before surgery on two patients with severe heart failure with the implanted artificial left ventricle. The repeated research showed that slow oscillations appeared and became "expressive and dominant" in the spectrum of R-R interval of the emptied heart; and they were absent in the spectrum of blood pressure.

According to Maliani et al. (1998), the origin of low-frequency and high-frequency waves of heart rhythm is conditioned by their complex central-peripheral organization and has a complex multicomponent nature. Therefore, the question of applying the methods of heart rate variability analysis to evaluate the autonomic balance of cardiac regulation accurately is debatable. Principles of the possibility of accurate evaluation of "sympathetic-parasympathetic balance" by means of the R-R interval spectrum indicators are supported by Malliani (1996, 1999), Pagani \& Malliani, 2000). The researcher considers that HF waves are determined by only parasympathetic influences, and LF - by sympathetic ones; the tone changes of two parts of autonomic nervous system occur reciprocally. However, a different view can be drawn from the analytical review of the literature (Eckberg, 1997; Kovalenko, 2005). In experiments (Koh et al., 1994; Martinmaki et al., 2006), respiratory and long-wave heart rhythms were eliminated with the blockade of M-cholinoreceptors in dogs and humans. No correlation was found between the spectral power at $0.1 \mathrm{~Hz}$ frequency and the release of norepinephrine during muscle stimulation (Kingwell et al., 1994).

The measurements (Shejh-Zade et al., 2001) show that the sympathetic nervous system can act on the heart rhythm through parasympathetic terminals, changing the frequency of their burst pulses. At the same time, the results of acute studies in cats show that heart rate variability "reflects a very specific interaction of myogenic, sympathetic and parasympathetic mechanisms aimed at economizing cardiac activity, but does not reflect the balance of tonic effects of extracardial nerves".

At the same time, according to spectral analysis of cardiac rhythm at gravitational loads, there is a redistribution of vegetative balance towards the predominance of its sympathetic link being, to some extent, a confirmation of the theory of A. Malliani (Hirayanagi et al., 1999). Changes in adrenaline/norepinephrine ratio in the urine of 13 swimmers during seven weeks of training correlated positively with $\mathrm{LF} / \mathrm{HF}$ index shifts $(\mathrm{r}=0.42$, $\mathrm{P}<0.03$ ) (Atlaoui et al., 2007). An increase in the normalized power of heart rate waves at low-frequency range is observed with stress influences (Dishman et al., 2000).

According to (Ruttkaj-Nedecki, 2001), criticism of this approach should not negate the possible benefit of calculating the $\mathrm{LF} / \mathrm{HF}$ ratio to characterize the state of regulation of the cardiovascular system. However, one must be more critical of the physiological interpretation of its changes.

It has been found (Wagner \& Persson, 1994) that the sympathovagal balance can be estimated from the wave amplitude of stroke blood volume or blood pressure in different frequency ranges. It is possible to bypass the controversial issues that arise in the analysis of R-R interval oscillations. Thus, studies of rats of the Wistar-Kyoto line and spontaneously hypertensive rats have shown that the power spectrum of blood pressure in the low frequency range is due to sympathetic influences through $\alpha_{1}$ adrenoreceptors (Dabire et al., 2002). Measurements of systolic pressure variability in persons with spinal cord injuries show that at breaks above $\mathrm{T}_{3}$ segment, the power of Mayer waves decreases and their normal re- 
sponse to orthostatic test changes (Munokata et al., 2001). Studies on runners (Portier et al., 2001) show after 3 weeks of rest and 12 weeks of endurance training that sympathovagal balance can be estimated by the ratio and changes in the power of blood pressure oscillations in the range of high and low frequencies. However, wave processes in blood pressure can be affected by not only cardiac output fluctuations but also modulation of peripheral vascular tone with sympathetic nerves, NO system activity (Chowdhary et al., 2002).

It has been found (Liu et al., 2004; Bar et al., 2009) that variability in blood pressure and stroke volume shows different information about the activity of autonomic nervous system than the analysis of changes in R-R interval duration. One of the factors may be the absence of plausible correlations between the capacities in the same oscillation ranges of different parameters and their changes during blockade of $\mathrm{M}$-choline and $\beta$-adrenoceptors, analysis of the relationship of their parameters with the pupil diameter and its response to light. When stimulating the carotid sinus by the creation of negative pressure at rest, an increase in the power of fast waves of blood pressure, slow waves of blood pressure and heart rate was observed. And at physical activity, such influence increased only the power of $\mathrm{BP}$ oscillations in the range of low frequencies.

The wave structure of the heart rhythm can be studied using autocorrelation analysis (Baevskyj et al., 2001). However, autocorrelation analysis can show nothing with the changes in the frequency of periodical process although there is latent rhythmic.

The structural linguistic method is suggested to analyze the changes in the spectrum form of R-R interval duration and the regularities of their transformation with different influences (Il'in et al., 2003); it helps to simplify the description of the changes while retaining the most important properties of information. Thus, it can be argued that the output tone of the autonomic nervous system can modulate changes in human haemodynamics in breathing hypocapnia and affect the features of long-term changes after the cessation of this influence.

\section{Conclusion}

The initial level of autonomic tone affects the dynamics of $\mathrm{CO}_{2}$ level in the alveolar air during hyperventilation and recovery period after it. A decrease in the duration of R-R interval was found during the hyperventilation test, being the most expressed in normotonic subjects. Heart index increased in all three groups and general peripheral resistance decreased mostly in the groups of normo- and parasympathicotonic subjects. At the same time, the reliable increase of stroke index and heart index was found. A decrease in the indicators of tension index and ejection speed and an increase in the duration of tension phase and ejection phase were observed in the recovery period after hyperventilation in normotonic subjects and especially parasympathicotonic compared to sympathicotonic ones.

\section{References}

Akselrod, S., Gordon, D., Ubel, F. A., Shannon, D. C., Berger, A. C., \& Cohen, R. J. (1981). Power spectrum analysis of the heart rate fluctuation: A quantative probe of beat to beat cardiovascular control. Science, 213, 220-222.

Allan, P. D., Faulkner, J., O'Donnell, T., Lanford, J., Wong, L. K., Saleem, S., Woolley, B., Lambrick, D., Stoner, L., \& Tzeng, Y. C. (2015). Hemodynamic variability and cerebrovascular control after transient cerebral ischemia. Physiological Reports, 3(11), e12602.

Appel, M. L., Berger, R. D., Saul, G. P., Smith, J. M., \& Cohen, R. J. (1989). Beat to beat variability in cardiovascular variables: Noise or music? Journal of the American College of Cardiology, 14, 1139-1148.

Atlaoui, D., Pichot, V., Lacoste, L., Barale, F., Lacour, J. R., \& Chatard, J. C. (2007) Heart rate variability, training variation and performance in elite swimmers. International Journal of Sports Medicine, 28(5), 394400.

Baevskij, R. M., Ivanov, G. G., Chirejkin, L. V., Gavrilushkin, A. P., Dovgalevskij, P. J., Kukushkin, J. A., Mironova, T. F., Priluckij, D. A., Semenov, A. V., Fedorov, V. F., Flejshman, A. N., \& Medvedev, M. M. (2001). Analiz variabel'nosti serdechnogo ritma pri ispol'zovanii razlichnykh elektrokardiograficheskikh sistem) [Analysis of heart rate variability when using different electrocardiographic systems]. Vestnik Aritmologii, 24, 65-87 (in Russian).

Bajmakanova, G. E. (2013). Interpretacija pokazatelej gazov arterial'noj krovi [Interpretation of arterial blood gases]. Pul'munologija i Alergologija, 2, 42-45 (in Russian)
Baković, D., Eterović, D., Valic, Z., Saratlija-Novaković, Ž., Palada, I., Obad, A., \& Dujić, Ž. (2006). Increased pulmonary vascular resistance and reduced stroke volume in association with $\mathrm{CO}_{2}$ retention and inferior vena cava dilatation. Journal of Applied Physiology, 101(3), 866-872.

Bär, K. J., Schulz, S., Koschke, M., Harzendorf, C., Gayde, S., Berg, W., Voss, A., Yeragani, V. K., \& Boettger, M. K. (2009). Correlations between the autonomic modulation of heart rate, blood pressure and the pupillary light reflex in healthy subjects. Journal of the neurological sciences, 15(279), 9-13.

Bernardi, L., Passino, C., Spadacini, G., Valle, F., Leuzzi, S., Piepoli, M., \& Sleight, P. (1997). Arterial baroreceptors as determinants of $0.1 \mathrm{~Hz}$ and respiration-related changes in blood pressure and heart rate spectra. Studies in Health Technology and Informatics, 35, 241-252.

Bhandare, A., Huckstepp, R., \& Dale, N. (2019). Analyzing the brainstem circuits for respiratory chemosensitivity in freely moving mice. BioRxiv, 492041, 1-15.

Boulet, L. M., Tymko, M. M., Jamieson, A. N., Ainslie, P. N., Skow, R. J., \& Day, T. A. (2016). Influence of prior hyperventilation duration on respiratory chemosensitivity and cerebrovascular reactivity during modified hyperoxic rebreathing. Experimental Physiology, 101(7), 821-835.

Bouteau, N., \& Tavernier, B. (2004). Stroke volume variation as an indicator of fluid responsiveness. Anesthesia and Analgesia, 98(1), 278-279.

Bukov, J. A., \& Belousova, I. M. (2016). Ispol'zovanie dyhatel'nogo trenazhera v uchebnom processe po fizicheskomu vospitaniju s cel'ju korrekcii ventiljacionnyh tipov u studentov podgotovitel'noj medicinskoj gruppy [The use of a breathing simulator in the educational process for physical education in order to correct ventilation types in students of the preparatory medical group]. Uchenye Zapiski Universiteta Imeni P. F. Lesgafta, 132, 49-54 (in Russian).

Burman, J., Lukkarinen, H., Elenius, V., Remes, S., Kuusela, T., \& Jartti, T. (2018). Eucapnic voluntary hyperventilation test in children. Clinical Physiology and Functional Imaging, 38(4), 718-720.

Cassaglia, P. A., Griffiths, R. I., \& Walker, A. M. (2008). Sympathetic withdrawal augments cerebral blood flow during acute hypercapnia in sleeping lambs. Sleep, 31(12), 1729-1734

Cevese, A., Grasso, R., Poltronieri, R., \& Schena, F. (1995). Vascular resistance and arterial pressure low-frequency oscillations in the anesthetized dog. American Journal Physiology, 268(1), 7-16.

Chowdhary, S., Ng, G. A., Nuttall, S. L., Coote, J. H., Ross, H. F., \& Townend, J. N. (2002). Nitric oxide and cardiac parasympathetic control in human heart failure. Clinical Science (London), 102(4), 397-402.

Cooley, R. L., Montano, N., \& Cogliati, C. (1998). Evidence for a central origin of low-frequency oscillation in RR-interval variability. Circulation, 98, 556-561.

Coverdale, N. S., Badrov, M. B., \& Shoemaker, J. K. (2016). Impact of age on cerebrovascular dilation versus reactivity to hypercapnia. Journal of Celebral Blood Flow and Metabolism, 37(1), 344-355.

Curley, G., Kavanagh, B. P., \& Laffey, J. G. (2010). Hypocapnia and the injured brain: More harm than benefit. Critical Care Medicine, 38(5), 1348-1359.

Dabire, H., Lacolley, P., Chaouche-Teyara, K., Fournier, B., \& Safar, M. E. (2002). Relationship between arterial distensibility and low-frequency power spectrum of blood pressure in spontaneously hypertensive rats. Journal of Cardiovascular Pharmacology, 39(1), 98-106.

Dishman, R. K., Nakamura, Y., Garsia, M. E., Thompson, R. W., Dunn, A. L., \& Blair, S. N. (2000). Heart rate variability, trait anxiety, and perceived stress among physically fit men and women. International Journal of Psychophysiology, 37(2), 121-133.

Djomin, D. B., \& Poskotinova, L. V. (2017). Analiz kolichestvennyh harakteristik EEG pri intensivnom ciklicheskom dyhanii s kontrolem urovnja gipokapnii [Analysis of the quantitative characteristics of the EEG in intensive cyclic respiration with control of the level of hypocapnia]. Vestnik Klinicheskoj Nejrofiziologii, 8, 17-18 (in Russian).

Drogovoz, S. M., Shtrigol', S. J., Kononenko, A. V., Zupanec, M. V., \& Shtroblja, A. L. (2016). Mehanizm dejstvija karboksiterapii [The mechanism of action of carboxytherapy]. Farmakologija ta Likars'ka Toksykologija, 6(51), 12-18 (in Russian).

Drogovoz, S. M., Shtrygol', S. J., Kononenko, A. V., Zupanec, M. V., Shtrigol', C. J., \& Zupanec', M. V. (2017). Farmakologicheskoe obosnovanie karboksiterapii $\left(\mathrm{CO}_{2}\right.$-terapii) [Pharmacological rationale for carboxytherapy $\left(\mathrm{CO}_{2}\right.$ therapy)]. Farmakologija ta Likars'ka Toksykologija, 52, 73-77 (in Russian).

Drogovoz, S. M., Shtrygol', S. J., Zupanec, M. V., Kononenko, A. V., \& Levinskaja, E. V. (2016). Fiziologicheskie svojstva $\mathrm{CO}_{2}$ - obosnovanie unikal'nosti karboksiterapii [Physiological properties of $\mathrm{CO}_{2}$ - justification for the uniqueness of carboxytherapy]. Medichna ta Klinichna Himija, 18(1), 112-116 (in Russian).

Eckberg, D. L. (1997). Sympathovagal balance. A critical appraisal. Circulation, $96,3224-3232$.

Eckberg, D. L., Cooke, W. H., Diedrich, A., Biaggioni, I., Buckey, J. C. Jr., Pawelczyk, J. A., Ertl, A. C., Cox, J. F., Kuusela, T. A., Tahvanainen, K. U., Mano, T., Iwase, S., Baisch, F. J., Levine, B. D., Adams-Huet, B., Robertson, D., \& Blomqvist, C. G. (2018). Respiratory modulation of human autonomic function on Earth. Journal Physiology, 594(19), 5611-5627. 
Falquetto, B., Oliveira, L. M., Takakura, A. C., Mulkey, D. K., \& Moreira, T. S. (2018). Inhibition of the hypercapnic ventilatory response by adenosine in the retrotrapezoid nucleus in awake rats. Neuropharmacology, 138, 47-56.

Fischer, K., Guensch, D. P., Shie, N., Lebel, J., \& Friedrich, M. G. (2016). Breathing maneuvers as a vasoactive stimulus for detecting inducible myocardial ischemia - an experimental cardiovascular magnetic resonance study. PLoS One, 11(10), e0164524.

Fischer, K., Yamaji, K., Luescher, S., Ueki, Y., Jung, B., von Tengg-Kobligk, H., Windecker, S., Friedrich, M. G., Eberle, B., \& Guensch, D. P. (2018). Feasibility of cardiovascular magnetic resonance to detect oxygenation deficits in patients with multi-vessel coronary artery disease triggered by breathing maneuvers. Journal of Cardiovascular Magnetic Resonance, 20(1), 31.

Foster, G. T., Vaziri, N. D., \& Sassoon, C. S. (2001). Respiratory alkalosis. Respiratory Care, 46(4), 384-391.

Gavrisjuk, V. K. (2006). Hronicheskoe legochnoe serdce: Mehanizmy patogeneza i principy terapii [Chronic pulmonary heart: Mechanisms of pathogenesis and principles of therapy]. Ukrainskyi Pulmonohichnyi Zhurnal, 4, 6-13 (in Russian).

Gnezdickij, V. V., Koshurnikova, E. E., Korepina, O. S., \& Skomorohov, A. A (2010). Analiz reakcij JeJeG na giperventiljaciju (trendy i dipol'naja lokalizacija): Problemy interpretacii [Analysis of EEG reactions to hyperventilation (trends and dipole localization): Interpretation problems]. Funkcional'naja Diagnostika, 1, 3-25 (in Russian).

Grishin, O. V., Averko, N. N., Zhilina, I. G., Grishin, V. G., \& Kovalenko, J. V. (2012). Psihogennaja odyshka i gipokapnija u bol'nyh ishemicheskoj bolezn'ju serdca do i posle koronarnogo shuntirovanija [Psychogenic dyspnea and hypocapnia in patients with coronary heart disease before and after coronary artery bypass grafting]. Angiologija i Sosudistaja Hirurgija. Patologija Krovoobrashhenija i Kardiohirurgija, 1, 39-42 (in Russian).

Grishin, O. V., Basalaeva, S. V., Umanceva, N. D., Ustjuzhaninova, N. V., Grishin, V. G., \& Mitrofanov, I. M. (2011). Uvelichenie skorosti vydelenija $\mathrm{CO}_{2}$ $\mathrm{v}$ pokoe pri kratkovremennoj gipoksii u zdorovyh ljudej [An increase in the rate of release of $\mathrm{CO}_{2}$ at rest with short-term hypoxia in healthy people]. Fiziologija Cheloveka, 37(5), 77-83 (in Russian).

Guyenet, P. G., Stometta, R. L., Abbott, S. B., Depuy, S. D., \& Kanbar, R. (2012) The retrotrapezoid nucleus and breathing. Arterial Chemoreception, 758, 115-122.

Guzzetti, S., Cogliati, C., Broggi, C., Carozzi, C., Cardirole, D., Lombardi, F., \& Malliani, A. (1994). Influences of neural mechanisms on heart period and arterial pressure variabilities in quadriplegic patients. American Journal of Physiology, 266, 1112-1120.

Hajutin, V. M., \& Lukoshkova, E. V. (1999). Spektral'nyj analiz kolebanij chastoty serdcebienij: Fiziologicheskie osnovy i oslozhnjajushhie ego javlenija [Spectral analysis of heart rate fluctuations: Physiological bases and its complicating phenomena]. Rossijskij Fiziologichnij Zhumal, 85(7), 893-909 (in Russian).

Harrison, J. M., Gilchrist, P. T., Corovic, T. S., Bogetti, C., Song, Y., Bacon, S. L., \& Ditto, B. (2017). Respiratory and hemodynamic contributions to emotionrelated pre-syncopal vasovagal symptoms. Biological Psychology, 127, 46-52.

Hirayanagi, K., Iwasaki, K., Sasaki, T., Kinugasa, H., Miyamoto, A., \& Yajima, K (1999). Sensitivity analyses of heart rate variability variables by incremental, passive head-up tilt. Uchu Koku Kankyo Igaku, 36(2), 67-74.

Hoiland, R. L., Fisher, J. A., \& Ainslie, P. N. (2019). Regulation of the cerebral circulation by arterial carbon dioxide. Comprehensive Physiology, 9(3), 1101-1154

Il'in, V. N., Batyrbekova, L. M., Kurdanova, M. H., \& Kurdanov, H. A. (2003) Ritmokardiograficheskie metody ocenki funkcional'nogo sostojanija organizma cheloveka [Rhythmocardiographic methods for assessing the functional state of the human body]. Servis-Shkola, Stavropol (in Russian).

Inoue, K., Miyake, S., Kumashiro, M., Ogata, H., \& Yoshimura, O. (1990). Power spectral analysis of heart rate variability in traumatic quadriplegic humans. American Journal of Physiology, 258, 1722-1726.

Introna, N., Yodlowski, E., Pruett, J., Montano, N., Porta, A., \& Crumrine, R (1995). Sympathovagal effects of spinal anesthesia in heart rate variability analysis. Anesthesia and Analgesia, 80, 313-321.

Jansen, B. J. A., Oosting J., \& Slaff, D. W. (1995). Hemodynamic basis of oscillation in systemic arterial pressure in conscious rat. American Journal of Physiology, 266(1), 62-71.

Kamath, M. V., \& Fallen, E. L. (1993). Power spectral analysis of heart rate variability: A noninvasive signature of cardiac autonomic function. Critical Reviews in Biomedical Engineering, 21, 245-311.

Kavanagh, B. (2002). Normocapnia vs hypercapnia. Minerva Anestesiologica, 68(5), 346-350.

Khiat, L., Gustavo, A., \& Leibaschoff, H. (2018). Clinical prospective study on the use of subcutaneous carboxytherapy in the treatment of diabetic foot ulcer. Surgical Technology International, 32, 1-10.

Kingwell, B. A., Thompson, J. M., Kaye, D. M., McPherson, G. A., Jennings, G. L., \& Esler, M. D. (1994). Heart rate spectral analysis, cardiac norepinephrine spillover, and muscle sympathetic nerve activity during human sympathetic nervous activation and failure. Circulation, 90, 234-240.
Klabunde, R. E. (2012). Neurohumoral control of the heart and circulation. Cardiovascular Physiology Concepts. 2nd edition. Lippincott Williams and Wilkins, Baltimore. Pp. 136-137.

Koh, J., Brown, T. E., Beightol, L. A., Ha, O. Y. \& Eckberg, D. L. (1994). Human autonomic rhythms: Vagal cardiac mechanisms in tetraplegic subjects. The Journal of Physiology (London), 474, 483-495.

Kovalenko, S. A., \& Kudii, L. I. (2006). Heart rate variability in subjects with different respiratory rates. Human Physiology, 32, 742-743.

Kovalenko, S. O. (2005). Analiz variabel'nosti sercevogo rytmu za dopomogoju metodu mediannoi' spektrogramy [Analysis of heart rate variability using the median spectrogram method]. Fiziologichnyj Zhurnal, 51(3), 92-95.

Kubichek, W. G., Patterson, R. P., \& Wetsol, D. A. (1970). Impedance cardiography as a noninvasive method of monitoring cardiac function and other parameters of the cardiovascular system. Annals of the New York Academy of Sciences, 2, 724-732

Kulikov, V. P., Kuznecova, D. V., \& Zarja, A. N. (2017). Cerebrovaskuljarnaja kardiovaskuljarnaja $\mathrm{CO}_{2}$ reaktivnost' v patogeneze arterial'noj gipertenzi [Cerebrovascular and cardiovascular $\mathrm{CO}_{2}$ reactivity in the pathogenesis of arterial hypertension]. Arterial'naja Gipertenzija, 23(5), 433-446 (in Russian).

Lafave, H. C., Zouboules, S. M., James, M. A., Purdy, G. M., Rees, J. L., Steinback, C. D., Ondrus, P., Brutsaert, T. D., Nysten, H. E., Nysten, C. E., Hoiland, R. L., Sherpa, M. T., \& Day, T. A. (2019). Steady-state cerebral blood flow regulation at altitude: Interaction between oxygen and carbon dioxide. European Journal of Applied Physiology, 119(11-12), 2529-2544.

Lakhno, I. V. (2017). The hemodynamic repercussions of the autonomic modulations in growth-restricted fetuses. Alexandria Journal of Medicine, 53(4), 333-336.

Leacy, J. K., Zouboules, S. M., Mann, C. R., Peltonen, J. D. B., Saran, G., Nysten, C. E., Nysten, H. E., Brutsaert, T. D., O’Halloran, K. D., Sherpa, M. T., \& Day, T. A. (2018). Neurovascular coupling remains intact during incremental ascent to high altitude $(4240 \mathrm{~m})$ in acclimatized healthy volunteers. Frontiers in Physiology, 28(9), 691.

Linden, D., \& Diehl, R. R. (1996). Comparison of standard autonomic tests and power spectral analysis in normal adults. Muscle and Nerve, 19, 556-562.

Liu, H., Yambe, T., Sasada, H., Nanka, S., Tanaka, A., Nagatomi, R., \& Nitta, S. (2004). Comparison of heart rate variability and stroke volume variability. Autonomic Neuroscience: Basic and Clinical, 116, 69-75.

Lucini, D., Mela, G. S., Malliani, A., \& Pagani, M. (1997). Evidence of increased sympathetic vasomotor drive with shorter acting dihydropyridine calcium channel antogonist in human hypertension: A study using spectral analysis of RR interval and systolic arterial pressure variability. Journal of Cardiovascular Pharmacology, 29, 676-683.

Lutsenko, O. I., \& Kovalenko, S. O. (2017). Blood pressure and hemodynamics: Mayer waves in different phases of ovarian and menstrual cycle in women. Physiological Research, 2, 235-240.

Lyzogub, V. G., Savchenko, A. V., Zapeka, J. S., \& Baytser, M. S. (2015). Rol' vuglekyslogo gazu $\mathrm{v}$ organizmi ljudyny [The role of carbon dioxide in the human body]. Pershyj Nezalezhnyj Naukovyj Visnyk, 4, 29-32 (in Russian).

Madureira, J., Castro, P., \& Azevedo, E. (2017). Demographic and systemic hemodynamic influences in mechanisms of cerebrovascular regulation in healthy adults. Journal of Stroke and Cerebrovascular Diseases, 26(3), 500-508.

Makarenkova, E. A., Malahov, M. V., Mel'nikov, A. A., \& Vikulov, A. D. (2012) Sravnitel'nyj analiz vlijanija proizvol'noj giperventiljacii i fizicheskoj nagruzk na funkciju ravnovesija cheloveka [Comparative analysis of the effect of voluntary hyperventilation and physical activity on the human equilibrium function] Jaroslavskij Pedagogicheskij Vestnik, 3(4), 145-148 (in Russian).

Malik, M., Hnatkova, K., Huikuri, H. V., Lombardi, F., Schmidt, G., \& Zabel, M (2019). CrossTalk proposal: Heart rate variability is a valid measure of cardiac autonomic responsiveness. Journal of Physiology, 597(10), 2595-2598.

Malliani, A. (1996). Heart rate variability: A challenge for a new way of thinking. Journal of Cardiac Failure, 2, 197-202.

Malliani, A. (1998). Fiziologicheskaja interpretacija spektral'nyh komponentov variabel'nosti serdechnogo ritma (HRV) [Physiological interpretation of spectral components of heart rate variability (HRV)]. Vestnik Aritmologii, 3, 47-57 (in Russian)

Malliani, A. (1999). The pattern of sympathovagal balance explored in the frequency domain. News of Physiological Sciences, 14, 111-117.

Malliani, A., Pagani, M., \& Lombardi, F. (1994). Physiology and clinical implications of variability of cardiovascular parameters with focus on heart rate and blood pressure. American Journal of Cardiology, 73(7), 3-9.

Malliani, A., Pagani, M., Lombardi, F., \& Cerutti, S. (1991). Cardiovascular neural regulation explored in the frequency domain. Circulation, 84, 1482-1492.

Martinmaki, K., Rusko, H., Kooistra, L., Kettunen, J., \& Saalasti, S. (2006). Intraindividual validation of heart rate variability indexes to measure vagal effects on hearts. American Journal of Physiology / Heart and Circulatory Physiology, 290(2), 640-647.

Meng, L., \& Gelb, A. W. (2015). Regulation of cerebral autoregulation by carbon dioxide. Anesthesiology, 122(1), 196-205. 
Miller, K. B., Howery, A. J., Harvey, R. E., Eldridge, M. W., \& Barnes, J. N. (2018). Cerebrovascular reactivity and central arterial stiffness in habitually exercising healthy adults. Frontiers in Physiology, 9, 1096.

Mishustin, J. N. (2007). Vyhod iz tupika. Oshibki mediciny ispravljaet fiziologija [Breaking the deadlock. Errors of medicine are corrected by physiology]. Samarskij Dom Pechati, Samara (in Russian).

Montano, N., Riscone, T. G., Porta, A., Lombardi, F., Pagani, M., \& Malliani, A. (1994). Power spectrum analysis of heart rate variability to assess the changes in sympathovagal balance during graded orthostatic tilt. Circulation, 90, $1826-1831$

Morgan, W. P. (1983). Hyperventilation syndrome: A review. American Industrial Hygiene Association Journal, 44(9), 685-689.

Munakata, M., Kameyama, J., Nunokawa, T., Ito, N., \& Yoshinaga, K. (2001) Altered Mayer wave and baroreflex in high spinal cord injury. American Journal of Hypertension, 14(2), 141-148.

Mutch, W. A. C., El-Gabalawy, R., Girling, L., Kilborn, K., \& Jacobsohn, E. (2018) End-Tidal hypocapnia under anesthesia predicts postoperative delirium. Frontiers in Neurology, 9, 678.

Myers, C. W., Cohen, M. A., Eckberg, D. L., \& Taylor, J. A. (2001). A model for the genesis of arterial pressure Mayer waves from heart rate and sympathetic activity. Autonomic Neuroscience: Basic and Clinical, 91(1-2), 62-75.

Nagibovich, O. A., Uhovskij, D. M., Zhekalov, A. N., Tkachuk, N. A., Arzhavkina, L. G., Bogdanova, E. G., Murzina, E. V., \& Belikova T. M. (2016). Mehanizmy gipoksii v Arkticheskoj zone Rossijskoj Federacii [Hypoxia mechanisms in the Arctic zone of the Russian Federation]. Vestnik Rossijskoj Voenno-Medicinskoj Akademii, 54, 202-205 (in Russian).

Novak, V., Novak, P., de Champlain, J., \& Nadeau, R. (1994). Altered cardiorespiratory transfer in hypertension. Hypertension, 23, 104-113.

Pagani, M., \& Malliani, A. (2000). Interpreting oscillation of muscle sympathetic nerve activity and heart rate variability. Joumal of Hypertension, 18, 1709-1719.

Panina, M. I. (2003). Patofiziologicheskie aspekty giperventiljacii i giperventiljacionnogo sindroma [Pathophysiological aspects of hyperventilation and hyperventilation syndrome]. Kazanskij Medicinskij Zhurnal, 84(4), 288-293. (in Russian).

Pomeranz, M., Macaulay, R. J. B., \& Caudill, M. A. (1985). Assessment of anatomic function in humans by heart rate spectral analysis. American Journal of Physiology, 248, 151-153.

Ponimasov, O. E. (2016). Jeksternal'nye projavlenija gipokapnii pri podvodnom nyrjanii bez dyhatel'nogo apparata [External manifestations of hypocapnia with underwater diving without a breathing apparatus]. Innovacionnaja Nauka: Proshloe, Nastojashhee, Budushhee, 4, 145-147 (in Russian).

Portier, H., Lonisy, F., Lande, D., Berthelot, M., \& Guezennee, C. Y. (2001) Intense endurance training on heart rate and blood pressure variability in runners. Medicine and Science in Sports and Exercise, 33(7), 1120-1125.

Raamat, R., Jagomägi, K., Talts, J., Toska, K., \& Walløe, L. (2003). Beat-to-beat measurement of the finger arterial pressure pulse shape index at rest and during exercise. Clinical Physiology and Functional Imaging, 23(2), 87-91.

Rimoldi, O., Pierimi, S., Ferrari, A., Cerutti, S., Pagani, M., \& Malliani, A. (1990) Analysis of short-term oscillation of R-R and arterial pressure in conscious dogs. American Journal of Physiology, 258, 967-976.

Ruttkaj-Nedecki, I. (2001). Problemy jelektrokardiologicheskoj ocenki vlijanija vegetativnoj nervnoj sitemy na serdce [Problems of electrocardiological evaluation of the influence of the autonomic nervous system on the heart] Vestnik Aritmologii, 22, 56-60 (in Russian).

Salinet, A. S. M., Minhas, J. S., Panerai, R. B., Bor-Seng-Shu, E., \& Robinson, T. G. (2019). Do acute stroke patients develop hypocapnia? A systematic review and meta-analysis. Journal of the Neurological Sciences, 402, 30-39.

Sanderson, J. E., Yeung, L. Y., Yeung, D. T., Kay, R. L., Tomlinson, B., Critchley, J. A., Woo, K. S., \& Bernardi, L. (1996). Impact of changes in respiratory frequency and posture on power spectral analysis of heart rate and systolic blood pressure variability in normal subjects and patients with heart failure. Clinical Scienses (London), 91(1), 35-43.

Sato, K., Sadamoto, T., Hirasawa, A., Oue, A., Subudhi, A. W., Miyazawa, T., \& Ogoh, S. (2012). Differential blood flow responses to $\mathrm{CO}_{2}$ in human internal and external carotid and vertebral arteries. Journal of Physiology, 590(14), 3277-3290.

Semenov, A. M. (2016). Osoblivosti reguljaciï funkcional'nogo stanu ljudini dihal'noju gimnastikoju ta masazhem [Features of regulation of the functional state of the person by respiratory gymnastics and massage]. Naukovij Chasopis NPU Imeni M. P. Dragomanova, 71, 303-306 (in Russian).

Sesay, M., Tanzin-Fin, P., Gosse, P., Ballanger, P., \& Maurette, P. (2008). Real-time heart rate variability and its correlation with plasma cathecholamines during laparoscopic adrenal pheochromocytoma surgery. Anesthisia and Analgesia, 106(1), 164-170

Shaov, M. T., Shaova, Z. A., \& Pshikova, O. V. (2009). Izmenenie koncentracil uglekislogo gaza $v$ krovi cheloveka pod vozdejstviem jelektroakusticheskih signalov nervnyh kletok [Change in the concentration of carbon dioxide in the blood of a person under the influence of electro-acoustic signals of nerve cells]. Jug Rossii: Jekologija, Razvitie, 1, 136-141 (in Russian).

Shejh-Zade, J. R., Skibickij, V. V., Kathanov, A. M., Shejh-Zade, K. J., Suhomlinov, V. V., Kudrjashov, E. A., Cherednik, N. L., Zhukova, E. V., Kablov, R. N., \& Zuzik, J. A. (2001). Al'ternativnyj podhod k ocenke variabel'nosti serdechnogo ritma [An alternative approach to assessing heart rate variability]. Vestnik Aritmologii, 22, 49-55 (in Russian)

Shoemaker, J. K., O’Leary, D. D., \& Hughson, R. L. (2001). PET $\mathrm{CO}_{2}$ inversely affects MSNA response to orthostatic stress. Heat and circulatory physiology, 281(3), H1040-H1046.

Shurygin, I. A. (2000). Monitoring dyhanija: Pul'soksimetrija, kapnografija, oksimetrija [Respiratory monitoring: Pulse oximetry, capnography, oximetry] Binom, Moscow (in Russian).

Sigurdsson, M. I., Waldron, N. H., Bortsov, A. V., Smith, S. B., \& Maixner, W. (2018). Genomics of cardiovascular measures of autonomic tone. Joumal of Cardiovascular Pharmacology, 71(3), 180-191.

Singh, U. P. (2017). Evidence-based role of hypercapnia and exhalation phase in vagus nerve stimulation: Insights into hypercapnic yoga breathing exercises. Journal of Yoga and Physical Therapy, 7(3), 1000270-1000276.

Skyba, O., Pshenychna, L., \& Ustymenko-Kosorich, O. (2017). The features of vegetative regulation of the heart rate in athletes with different levels of perception and processing of visual information. Regulatory Mechanisms in Biosystems, 8(2), 239-243.

Smielewski, P., Steiner, L., Puppo, C., Budohoski, K, Varsos, G. V., \& Czosnyka, M. (2018). Effect of mild hypocapnia on critical closing pressure and other mechanoelastic parameters of the cerebrospinal system. Acta Neurochirgica Supplement, 126, 139-142

Solov'eva, A. V., Bjalovskij, J. J., \& Rakita, D. R. (2009). Osobennosti legochnogo gazoobmena pri metabolicheskom syndrome [Features of pulmonary gas exchange in the metabolic syndrome]. Doktor Ru, 79, 90-94 (in Russian).

Spitsin, A. P., Pershina, T. A., \& Tsarev, Y. K. (2018). Peculiarities of hemodynamics and heart rhythm in males with increased arterial pressure depending on initial vegetative tone and age. Advences in Gerontology, 31(2), 260-265.

Stocchetti, N., Maas, A. I., Chieregato, A., \& Van Der Plas, A. A. (2005). Hyperventilation in head injury. Chest, 127(5), 1812-1827.

Sullivan, G. M., Kent, J. M., Kleber, M., Martinez, J. M., Yeragani, V. K., \& Gorman, J. M. (2004). Effects of hyperventilation on heart rate and QT variability in panic disorder pre- and post-treatment. Psychiatry Research, 125(1), 29-39.

Szabo, K., Lako, E., Juhasz, T., Rosengarten, B., Csiba, L., \& Olah, L. (2011). Hypocapnia induced vasoconstriction significantly inhibits the neurovascular coupling in humans. Journal of the Neurological Sciences, 309, 58-62.

Tamisier, R., Weiss, J. W., \& Pépin, J. L. (2018). Sleep biology up dates: Hemodynamic and autonomic control in sleep disorders. Metabolism, 84, 3-10.

Tomimatsu, T., Kakigano, A., Mimura, K., Kanayama, T., Koyama, S., Fujita, S., \& Kimura, T. (2012). Maternal hyperventilation during labor revisited: Its effects on fetal oxygenation. Reproductive Sciences, 19(11), 1169-1174.

Tsuji, B., Filingeri, D., Honda, Y., Eguchi, T., Fujii, N., Kondo, N., \& Nishiyasu, T. (2018). Effect of hypocapnia on the sensitivity of hyperthermic hyperventilation and the cerebrovascular response in resting heated humans. Joumal of Applied Physiology, 124(1), 225-233.

Van Diest, I., Verstappen, K., Aubert, A. E., Widjaja, D., Vansteenwegen, D., \& Vlemincx, E. (2014). Inhalation/exhalation ratio modulates the effect of slow breathing on heart rate variability and relaxation. Applied Psychophysiology and Biofeedback, 39(3-4), 171-180

Wagner, C. D., \& Persson, P. B. (1994). Two ranges in blood pressure power spectrum with different 1/f characteristics. American Journal of Physiology, 267(2), 449-454.

Wiesenack, C., Fiegl, C., Keyser, A., Prasser, C., \& Keyl, C. (2005). Assessment of fluid responsiveness in mechanically ventilated cardiac surgical patients. European Journal of Anaesthesiology, 22, 658-665.

Wilder, J. (1957). The law of initial value in neurology and psychiatry: Facts and problems. The Journal of Nervous and Mental Disease, 125(1), 73-86.

Willie, C. K., Macleod, D. B., Shaw, A. D., Smith, K. J., Tzeng, Y. C., Eves, N. D. Ikeda, K., Graham, J., Lewis, N. C., Day, T. A., \& Ainslie, P. N. (2012). Regional brain blood flow in man during acute changes in arterial blood gases. Journal of Physiology, 590(14), 3261-3275.

Willie, C. K., MacLeod, D. B., Smith, K. J., Lewis, N. C., Foster, G. E., Ikeda, K, Hoiland, R. L., \& Ainslie, P. N. (2015). The contribution of arterial blood gases in cerebral blood flow regulation and fuel utilization in man at high altitude. Journal of Cerebral Blood Flow and Metabolism, 35(5), 873-881.

Zav'jalova, O. R. (2011). Zastosuvannja vuglekislogo gazu v medichnij reabilitacii' [The use of carbon dioxide in medical rehabilitation]. Medichna Gidrologija ta Reabilitacija, 9(1), 72-83 (in Ukrainian)

Zouboules, S. M., Lafave, H. C., O'Halloran, K. D., Brutsaert, T. D., Nysten, H. E, Nysten, C. E., Steinback, C. D., Sherpa, M. T., \& Day, T. A. (2018). Renal reactivity: Acid-base compensation during incremental ascent to high altitude. Journal of Physiology, 596(24), 6191-6203. 